\title{
Excerpt from CANCERous
}

\author{
Matilde Sanchez
}

La même question revient encore et encore dans la poésie de Matilde Sanchez selon son manuscrit CANCERigène. Sanchez écrit de la poésie qui confronte le corps malade au discours médical sur le corps. A travers les passages réguliers des infirmières, les notes des médecins et les perceptions craintives, ces poèmes rappellent au lecteur les détails qui tissent le quotidien, les couleurs qui font toujours référence aux règles, aux lèvres, aux ventres et aux bouches qui se transforment en Judas, quand des mots violents alimentent un discours adjectival. Alors que la tentative d'expiration exige de l'oxygène et de réapprendre à s'oxygéner, la maladie se répand et coagule, forçant le corps à s'épancher dans des poches secrètes et cachées du langage. L'homme très amaigri seulement représente le corps malade, mais il redéfinit les questions / prière / poumons qui s'infiltrent dans les mots infectés.

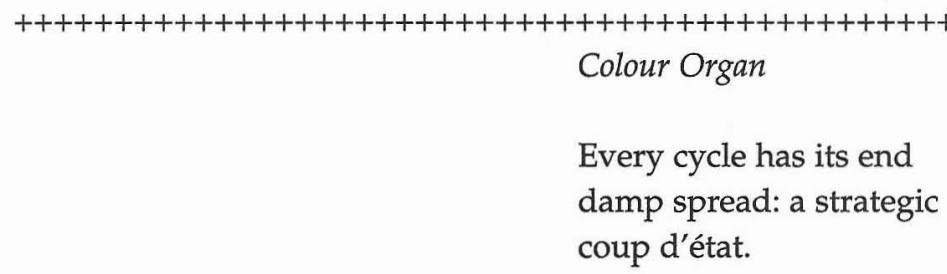

A whistle cry at midnight

the eagle on its prey:

salute, then undress.

Red stop in two evolutions from maroon mammal to red reptile snake skin: the favourite

Code RED: some quick rules no lights, no perfumed soaps, NO BRIGHT COLOURS, NO FLOWERS. 
Blues are holy - ok.

Green too nostalgic - no.

Yellow too suspect - never.

Taste the heat: colour spread

Not a prism, but ribs of white light

An expandable cage of

Translucent scales

molted for the colour organ

Another cavity created for disease

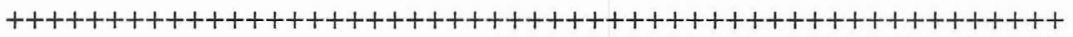

Nurse's Notes:

Cycle 1

- Visualize spokes around a wheel.

- The blood's redness drained white.

- Don't worry. The heart still knows how to work.

$+++++++++++++++++++++++++++++++++++++++++++++++++++++$ Thrown

webbed in this perfect pull

heaped as proof of a day's work

(just above the belly)

button puncture,

the mouth rabid with

a Judas kiss:

cracks the lips

kissed rabid

along the mouth

along the belly

mouth rabid 
with Judas

cracking on the lips

salts copper skin green

metallic veins bauble blue

melting belly button

(petal to puse)

pass through noon

her mudflat lips

Judased

rabid words

fuel the | heaped | I spun I | buttoned |

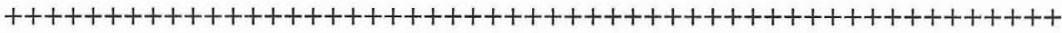

Nurse's Notes:

Cycle 2

- The body is fooled into a rare type of gestation.

- Morning sickness spins her mouth raw.

- The spokes fall away.

ivory old - older than the blood

on the pyramids

these wailing walls

lines as lives

broken and expanded

by cycles of fire

in folds of flesh

brick by brick

one breath

she breathes in a thousand years

etched in these walls

with teeth and tears -

facts that carve bodies 
in one breath

she draws as much blood as a syringe

enough blood

to sail these prayer flags

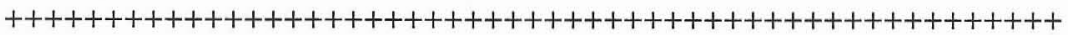
Breathe

heavy

azzurro-blue-leaves-quilted-together

heavy

for bedtime.

These leaves fall heavy. They sink in air.

It's hard to breathe in and out.

In.

Out.

Collapse the chest around the lungs

a radical compensation

for life

stumbling blue

lung-leaves cradled to feel the illness

that exhausts normal function.

Take the quilt off.

It's too heavy. I know you're cold.

An attempt to exhale

we breathe together with

quilted chests to push

the used air out

out of the lungs

past the tumor

a breached

breath 
the cancer

wants the lungs

tries to inhale

a trophy.

Fear pulls at the fingertips -

cuts them into exact $\mid$ cubes $\mid$ with fierce edges

that cannot breathe and cannot be quilted

and cannot warm scars into feeling flesh.

This aged body understands oxygen -

how it hurts the blood, but makes it red.

Air makes you old in the living but keeps you alive when you think you're dead.

$+++++++++++++++++++++++++++++++++++++++++++++++++++++$

Colour Organ II

Snowflake skin rolls out

into a paper thin evening

that melts white.

Lightning needles the thighs together

a fear of

ignites sequin knees

to puppet

this body of parts

sewn together with lighting threads

Choose between colours of

yellow, pink or red

Three colours c.l.o.t.t.e.d.

disease as suicide (red)

disease as alternate life (pink)

disease as gestation (yellow)

A whistle cry at midnight - the trill of dread

marks the assembly of teeth, lips, ears and tongues 
all life

lives

between closed eyes and burnt lungs.

Blue veins behind

a veil of buds knotted and kinked

lips eroded into

$$
\text { mud flats }
$$

cracked open to appreciate the afterglow

of radioactive isotopes

The Bone Scan Man says the

narrow marrow sample is undiseased for now.

$+++++++++++++++++++++++++++++++++++++++++++++++++++++$ Break out

"... sickness is the means by which an organism frees itself of foreign matter; so one must help it to be sick, to have its whole sickness and break out with it, for that is its progress." R.M. Rilke

Fear beads necklace ornaments at the nape of sickness leech blushed skin

Blood streamers

clot around

her stomach spun raw

bleeds into a cracked floor.

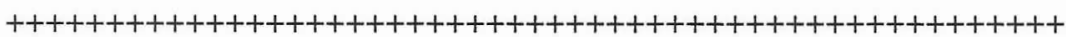

"Why aren't these lines filled out?"

words are ghosts caught in viles

between skin and hospital gowns 
pinned to cardboard for show and tell

"If you don't complete the form, how are we supposed to help you?" look between the walls

into petri dish eyes

listen for a pulse

"We are trying to make you well again. Please, give us all your information this time. I am your oncologist. I want to help you." look at this body of parts

a flesh and bone suspension

green and pulsing in front of you

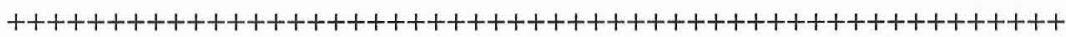
The way white and fear blend $\mathrm{g}=\mathrm{e}=1$ into snow flesh frozen awake removed then hanged in public galleries one thing gone missing but not knowing what ghosts with cold hands expose ribs of morning worse than salt water on mudflat lips

bloody

Mother of Pearl 
vacant

sea shell

flecks of opal blue

bloom rain wire

a teeming tongue

wraps sweet around

secret pulses of double

helix coils

shell threads spiral

sew you up

sutures spoiled by rain water

stitches along an IV jugular

dissolve into spokes of rust ash

a poisonous core

+++++++++++++++++++++++++++++++++++++++++++++++++++++

Nurse's Notes:

Cycle 8

- dimpled skin moulds, reprint her

- a type of birthing after illness

- the bone scan man holds her hand (she says he has hands of flint)

- she wears perfume behind her knees

to remind her of Dandelions 